\title{
Does the use of mouthwash before collecting saliva specimen increase the possibility of a false-negative result in COVID-19 testing?
}

\author{
Kaveh Nasiri ${ }^{1 *}$, Aleksandra Dimitrova ${ }^{2}$ and Kamyar Nasiri ${ }^{3}$ \\ ${ }^{1}$ Independent Researcher, Essen, Germany \\ ${ }^{2} \mathrm{MD}$, Department of Hematology, Internal Oncology \& Stem Cell Transplant, Evang. Hospital Essen-Werden, Essen, Germany \\ ${ }^{3} \mathrm{DDS}$
}

\section{Mini review}

A complex bio-fluid, saliva is secreted by major and minor salivary glands in the oral cavity. It is composed of protein and peptides, hormones, antibodies, and other molecular components, which are helpful for the examination of the physiological and pathological conditions of the human body. Saliva is currently used for the detection of different types of cancer, including oral, breast, and lung cancer, periodontal diseases, diabetes, and acute respiratory syndrome. It is, indeed, considered as a diagnostic window for various pathological diseases $[1,2]$.

SARS-CoV-2 consists of four main proteins; spike (S), membrane $(\mathrm{M})$, envelope (E), and nucleocapsid $(\mathrm{N})$. The anatomy of the spike protein facilitates the route transmission of the virus by attaching to the angiotensin-converting enzyme 2 (ACE-2). ACE-2 epithelial cells cover the salivary gland ducts, which are the primary target cells of SARSCoV-2 [3]. As reported in previous studies, the viral load of SARS$\mathrm{CoV}-2$ is high in saliva specimen [4,5]. This mini review focused on the effect of four types of mouthwash on the viral load of COVID-19 in saliva specimen.

Mouthwash or oral rinse is a liquid that is used in various ways; it is mainly held passively for a short period of time in the mouth to improve the oral hygiene. Mouthwashes are often used before dental procedures to reduce the microorganisms in the oral cavity. They are of different types, including but not limited to chlorhexidine (CHX), hydrogen peroxide $\left(\mathrm{H}_{2} \mathrm{O}_{2}\right)$, povidone-iodine (PVP-I), and cetylpyridinium chloride (CPC) [6-8].

Chlorhexidine (CHX) is one of the most commonly used antiseptics in dentistry against Gram-positive and Gram-negative bacteria and an alternative to mechanical oral hygiene procedures [6,7]. However, there is no satisfactory evidence that CHX is capable of inactivating the virus, particularly COVID-19; Yoon et al. [5] demonstrated that in two patients gargling with CHX, after one and two hours, the viral load of SARS-CoV-2 could not be detected.

Hydrogen peroxide $\left(\mathrm{H}_{2} \mathrm{O}_{2}\right)$ is a clear, colorless, and odorless liquid which is used as a mouthrinse at concentration of $1 \%$ to $3 \%[6,9]$. The study by Mentel et al. [10] demonstrated that $3 \% \mathrm{H}_{2} \mathrm{O}_{2}$ can inactivate the following viruses; influenza $\mathrm{A}$ and $\mathrm{B}$, adenovirus types 3 and 6, rhinovirus, myxoviruse, and coronavirus strain $229 \mathrm{E}$. In contrast, another study reported that 30 seconds gargling with $\mathrm{H}_{2} \mathrm{O}_{2}$ at $1.5 \%$ and $3 \%$ concentrations had minimal effect against COVID-19 [11].
Povidone-iodine (PVP-I) is also used to control and prevent infection and is available as a surgical skin antiseptic and mouthwash. PVP-I has antibacterial and antiviral effect [12]. In the study by Eggers et al. [12], PVP-I was utilized as a gargle or mouthwash at 7\% concentration and demonstrated rapid bactericidal and virucidal effect. In addition, PVP-I at a concentration of $0.23 \%$ may reduce the viral load of the virus, improve the oral hygiene, and decrease the cross infection [12]. Bidra et al. [11] also showed that PVP-I at concentrations of $0.5 \%$, $1.25 \%$, and $1.5 \%$ is capable of completely inactivating SARS-CoV-2 after 15 -second and 30 -second contact times.

Cetylpyridinium chloride (CPC) is a widely used antimicrobial agent for the purpose of enhancing gum health and effective against dental plaque and gingivitis at a concentration of $0.05 \%$ [13]. While CPC has showed direct virucidal effect against influenza viruses by disrupting the viral structure [14], there is no evidence of the efficacy of CPC versus SARS-CoV-2.

Saliva specimen is considered as a safe method for the detection of COVID-19 and previous studies reported satisfactory results in regard to the detection of viral load of SARS-CoV-2 $[15,16]$. Collecting saliva samples reduces the risk of contamination with COVID-19 for health workers as it can be collected by spitting into a sterile bottle and thus, the presence of trained health care workers is not required $[1,3]$.

Based on the foregoing information in this review, it seems that mouthwashes can decrease the required viral load of SARS-CoV-2 in order for the virus to be detected, which can lead to false-negative result. Thus, the use of mouthwashes before saliva sampling is not recommended. Finally, gargling with mouthwashes, particularly PVP-I, may have the potential to decrease cross infection in this pandemic.

\section{Sources of support}

Self-financed.

${ }^{*}$ Correspondence to: Kaveh Nasiri, DDS, MSc, Independent Researcher, Essen 45138, Germany, E-mail: DDS.Nasiri@web.de, ORCID ID: https://orcid. org/0000-0001-5571-0550

Key words: COVID-19, mouthwash, saliva

Received: July 29, 2020; Accepted: August 10, 2020; Published: August 14, 2020 


\section{Financial support and sponsorship}

Nil.

\section{References}

1. Nasiri K (2020) COVID-19 and the Antiviral Effect of Saliva. Eur J Dent. [Crossref]

2. Khurshid Z, Asiri FYI, Al Wadaani H (2020) Human Saliva: Non-Invasive Fluid for Detecting Novel Coronavirus (2019-nCoV). Int J Environ Res Public Health 17: 2225. [Crossref]

3. Nasiri K (2020) Human saliva as an effective sample for the detection of COVID-19. Dent Oral Maxillofac Res 6: 1-2. [Crossref]

4. Wyllie AL, Fournier J, Casanovas-Massana A, Campbell M, Tokuyama M, et al. (2020) Saliva or Nasopharyngeal Swab Specimens for Detection of SARS-CoV-2. $N$ Engl J Med 383: 1283-1286. [Crossref]

5. Yoon JG, Yoon J, Song JY, Yoon SY, Lim CS, et al. (2020) Clinical Significance of a High SARS-CoV-2 Viral Load in the Saliva. J Korean Med Sci 35: e195. [Crossref]

6. Vergara-Buenaventura A, Castro-Ruiz C (2020) Use of mouthwashes against COVID-19 in dentistry. Br J Oral Maxillofac Surg 58: 924-927. [Crossref]

7. Varoni E, Tarce M, Lodi G, Carrassi A (2012) Chlorhexidine (CHX) in dentistry: state of the art. Minerva Stomatol 61: 399-419. [Crossref]

8. Gercina AC, de Souza Amorim K, Pagaduan R, de Almeida Souza LM, Groppo FC (2020) What is the best mouthrinse against Coronaviruses? Oral Surg 13: 10.1111/ ors. [Crossref]
9. Walsh LJ (2000) Safety issues relating to the use of hydrogen peroxide in dentistry. Aust Dent J 45: 257-269. [Crossref]

10. Mentel R, Shirrmakher R, Kevich A, Drě̌zin RS, Shmidt I (1977) Virus inactivation by hydrogen peroxide. Vopr Virusol : 731-733. [Crossref]

11. Bidra AS, Pelletier JS, Westover JB, Frank S, Brown SM, et al. (2020) Comparison of In Vitro Inactivation of SARS CoV-2 with Hydrogen Peroxide and Povidone-Iodine Oral Antiseptic Rinses. J Prosthodont 29: 599-603. [Crossref]

12. Eggers M, Koburger-Janssen T, Eickmann M, Zorn J (2018) In Vitro Bactericidal and Virucidal Efficacy of Povidone-Iodine Gargle/Mouthwash Against Respiratory and Oral Tract Pathogens. Infect Dis Ther 7: 249-259. [Crossref]

13. Silva MF, dos Santos NB, Stewart B, DeVizio W, Proskin HM (2009) A clinica investigation of the efficacy of a commercial mouthrinse containing $0.05 \%$ cetylpyridinium chloride to control established dental plaque and gingivitis. JClin Dent 20: 55-61. [Crossref]

14. Popkin DL, Zilka S, Dimaano M, Fujioka H, Rackley C, et al. (2017) Cetylpyridinium Chloride (CPC) Exhibits Potent, Rapid Activity Against Influenza Viruses in vitro and in vivo. Pathog Immun 2: 252-269. [Crossref]

15. Zhu J, Guo J, Xu Y, Chen X (2020) Viral dynamics of SARS-CoV-2 in saliva from infected patients. J Infect 81: e48-e50. [Crossref]

16. Yokota I, Hattori T, Shane PY, Konno S, Nagasaka A, et al. (2020) Equivalent SARS$\mathrm{CoV}-2$ viral loads between nasopharyngeal swab and saliva in symptomatic patients. medRxiv. [Crossref]

Copyright: (C2020 Nasiri K. This is an open-access article distributed under the terms of the Creative Commons Attribution License, which permits unrestricted use, distribution, and reproduction in any medium, provided the original author and source are credited. 